\title{
INOVASI, PERTUMBUHAN, UKURAN DAN NILAI PERUSAHAAN FARMASI DI INDONESIA
}

\author{
Mursalim Nohong \\ Fakultas Ekonomi dan Bisnis Universitas Hasanuddin \\ Jalan Pertintis Kemerdekaan KM. 10, Makassar, 90245
}

\begin{abstract}
This research was based on the strategic role of firm innovation. For a pharmaceutical company, innovation drives the firm to expand new product which responsive to the needs of public health. The purpose of this study was to explain the innovation role on growth, size, and the value of pharmaceutical company in Indonesia. The Secondary data in 2011 - 2014 period, ten sample uses pharmaceutical companies listed on the Indonesia Stock Exchange. Data were analyzed using Structural Equation Modeling with PLS. The research results show that innovation were able to increase growth, size and company value.
\end{abstract}

Keyword: Innovation, Growth, Size, company value

\section{PENDAHULUAN}

Inovasi bagi perusahaan tidak sekedar proses untuk menghasilkan produk baru. Inovasi menjadi satu dengan perkembangan perusahaan. Inovasi diartikan sebagai suatu mekanisme atau cara untuk mengubah nilai dan kepuasan yang diperoleh konsumen dari sumbernya (Drucker, 1985). Schumpeter (1949) mendefinisikan inovasi sebagai; 1).Pengenalan pada industri metode produksi baru, 2).Pembukaan pasar baru dalam Negara, 3). Pencapaian sumber-sumber bahan baku baru, 4). Pembukaan pasar baru, dan 4). Penciptaan struktur organisasi baru dalam industri. Pada industri farmasi terdapat tiga alternatif inovasi yang dapat dilakukan yaitu; 1).Inovasi produk, 2).Inovasi layanan, dan 3).Inovasi model bisnis (Sundbo, 1997; Moore, 2004; Treacy, 2013).

Meskipun memiliki peran yang sangat strategis, bagi perusahaan farmasi keberadaan kegiatan inovasi belum mendapatkan perhatian yang tinggi sebagaimana ditunjukkan pada alokasi anggaran untuk kegiatan terkait seperti anggaran untuk penelitian dan pengembangan. Pengeluaran perusahaan untuk kegiatan-kegiatan yang terkait dengan inovasi masih lebih rendah dibandingkan dengan kegiatan pemasaran. Sebagai perusahaan yang terkait langsung dengan kebutuhan hidup manusia akan kesehatan, maka perusahaan farmasi dituntut untuk senantiasa berinovasi yang bertujuan untuk differensiasi produk maupun sebagai upaya memenuhi kebutuhan masyarakat akan ketersediaan produk-

Korespondensi dengan Penulis:

Mursalim Nohong: +62 81252126688

Email: mursalim1906nohong@gmail.com 


\section{Inovasi, Pertumbuhan, Ukuran dan Nilai Perusahaan Farmasi di Indonesia}

Mursalim Nohong

produk farmasi seperti obat-obatan. Peran-peran strategis inovasi terhadap kinerja (pertumbuhan) dan nilai perusahaan telah dibuktikan pada beberapa penelitian sepertiyang dilakukan oleh Cameron (1998), Cainelli et al., (2006) dan Bishop et al.,(2009).

Hasil penelitian tersebut menunjukkan adanya hubungan antara inovasi yang dilakukan perusahaan dengan pertumbuhan perusahaan. Penelitian tersebut menyimpulkan bahwa perusahaan yang melakukan inovasi memiliki kinerja atau pertumbuhan yang lebih baik dibandingkan dengan yang tidak melakukan inovasi.Inovasi perusahaan juga memiliki pengaruh terhadap karakteristik perusahaan (ukuran perusahaan) (Bosma dan de Wit, 2004).Hasil penelitian tersebut juga diperkuat oleh penelitian Mason etal., (2009) yang menemukan bahwa perusahaan yang lebih inovatif tumbuh lebih cepat (yang diukur dengan persentase penjualan dari produk-produk baru).Perusahaan yang inovatif mengalami pertumbuhan sekira 10 persen dibandingkan perusahaan lainnya yang kurang inovatif.

Tujuan utama dari setiap perusahaan adalah untuk memaksimalkan kekayaan pemegang saham dengan memaksimalkan keuntungan. Sebuah perusahaan harus berhati-hati dalam membuat keputusan dikaitkan dengan dampak yang akan dihadapi oleh para pemegang saham. Sebagai perusahaan publik, setiap kegiatan perusahaan akan diawasi oleh pasar dan mewakili harga saham. Oleh karena itu, tujuan utama dari sebuah perusahaan harus memaksimalkan kekayaan pemilik atau ekuivalen untuk memaksimalkan harga saham. Untuk mencapai tujuan tersebut, perusahaan perlu untuk memaksimalkan nilai (Rafindaand Noveria, 2014). Maksimalisasi nilai perusahaan dapat ditingkatkan melalui kegiatankegiatan inovasi.

Sasaran kegiatan inovasi perusahaan sebaiknya tidak sekedar untuk mendifferensiasikan produk atau jasanya dalam hubungannya dengan pesaing atau sekadar untuk merespon permintaan pasar. Inovasi perusahaan yang optimal perlu pula diarahkan pada penciptaan laba (Geroski et al., 1997; Leiponen, 2000; Cefis and Ciccarelli, 2005) dan peningkatan nilai perusahaan (Belenzon and Patacconi, 2013).

Untuk mengoptimalkan peran strategis inovasi terhadap kinerja dan nilai perusahaan, maka diperlukan pula kajian mengenai keterkaitan antara inovasi dengan karakteristik perusahaan seperti ukuran dan usia perusahaan, orientasi pada pasar luar, hambatan pendanaan inovasi, tingkat persaingan, situasi ekonomi negara (Zemplinerová dan Hromádková, 2012). Nicolau dan Maria (2013) mengemukakan adanyan hubungan antara karakteristik perusahaan, pertumbuhan perusahaan

Nicolau dan Maria (2013) menjelaskan bahwa inovasi yang dilakukan perusahaan akan dapat meningkatkan nilai perusahaan. Pendapat tersebut telah dibuktikan melalui hasil penelitian Berzkalne and Zelgalve (2014). Dari penelitian tersebut disimpulkan bahwa terdapat perbedaan nilai antara perusahaan yang inovatif dengan lainnya. Dari penelitian tersebut ditemukan pula bahwa perusahaan yang memberikan perhatian terhadap inovasi memiliki nilai yang lebih baik dibandingkan dengan perusahaan yang kegiatan inovasinya kecil.

Sujono (2010) menjelaskan bahwa kemampuan perusahaan untuk melakukan inovasi ditentukan oleh struktur kepemilikan, ketersediaan sumberdaya dan ukuran perusahaan. Faktor usia (age), ukuran (size), strategic features, hambatan inovasi keuangan, tingkat persaingan pasar, situasi ekonomi negara dan subsidi Research and Development juga menjadi faktor penentu inovasi (Zemplinerová and Hromádková, 2012).

Nilai perusahaan memiliki arti yang sangat penting dalam perkembangan perusahaan karena mencerminkan respon pasar. Respon yang diberikan investor atau pasar akan diwujudkan melaui perkembangan harga saham ataupun pertumbuhan perusahaan. Nilai perusahaan merupakan harga yang bersedia dibayar oleh investor apabila per- 


\section{Jurnal Keuangan dan Perbankan | KEUANGAN}

Vol. 20, No.2, Mei 2016: 176- 185

usahaan tersebut memperdagangkan sahamnya di pasa modal.Akan tetapi, nilai kekayaan yang ditunjukkan pada neaca tidak memiliki hubungan dengan nilai pasar perusahaan.Menurut Erlangga dan Suryandari (2009) hal ini disebabkan karena perusahaan memiliki kekayaan yang tidak bisa dilaporkan dalam neraca seperti manajemen yang baik, reputasi yang baik dan prospek yang cerah.

\section{PENGEMBANGAN HIPOTESIS}

Inovasi merupakan faktor penentu dalam persaingan industri dan menjadi senjata yang tangguh dalam menghadapi persaingan. Perusahaan yang inovatif akan unggul dalam persaingan dengan senantiasa menemukan produk ataupun jasa yang sesuai dengan kebutuhan pelanggan. Fokus utama inovasi adalah penciptaan gagasan baru, yang ada gilirannya akan diimplementasikan ke dalam penemuan produk baru atau proses baru. Pendekatan strukturalis memandang inovasi sebagai suatu unit dengan parameter yang tetap seperti teknologi dan praktek manajemen, sedangkan pendekatan proses memandang inovasi sebagai suatu proses yang kompleks, yang sering melibatkan berbagai kelompok sosial dalam organisasi (Swan et al., 1999).

Keputusan perusahaan untuk melakukan inovasi merupakan yang sangat strategis. Inovasi tidak saja menemukan produk atau proses baru, tetapi juga dibutuhkan keputusan untuk melakukan investasi R \& D. Penelitian dan pengembangan (R \& D) sebagai bagian dari aktivitas inovasi dapat dan harus digunakan oleh perusahaan dan industri untuk mengembangkan produk yang lebih baik serta memperbaiki proses sesuai dengan preferensi pelanggan. Oleh karena itu, inovasi diindikasikan oleh keberadaan perbaikan dalam proses internal organisasi dan perusahaan yang memungkinkan adanya pengurangan biaya dan penciptaan nilai (Zemplinerová dan Hromádková, 2012). Dorongan untuk melakukan investasi R \& D berdampak pada ukuran perusahaan dan pertumbuhan perusahaan karena setiap inovasi dan $\mathrm{R} \& \mathrm{D}$ akan menambah asset tetap perusahaan seperti mesin, peralatan dan perangkat teknologi. Berdasarkan pernyataan tersebut dapat dirumuskan hipotesis sebagai berikut: $\mathrm{H}_{1}$ : Terdapat pengaruh signifikan antara inovasi dengan ukuran perusahaan

Pertumbuhan sebuah bisnis tidak bisa dilepaskan dari kemampuan melakukan inovasi dalam segala hal. Banyak perusahaan besar yang bisa bertahan dan mampu membukukan keuntungan bisnis yang semakin besar karena kreatif dalam melakukan inovasi bisnis. Akan tetapi, banyak perusahaan yang ingin mencapai pertumbuhan hanya mengandalkan jumlah pelanggan. Padahal, tidak semua pelanggan dapat diandalkan sehingga diperlukan langkah strategis lainnya seperti pembinaan pelanggan. Oleh karena itu, untuk mendorong pertumbuhan perusahaan juga perlu mengusahakan terjadinya peningkatan yang berkesinambugan dan inovasi perusahaan. Oleh karena itu dapat dirumuskan hipotesis sebagai berikut:

\section{$\mathrm{H}_{2}$ : Terdapat pengaruh signifikan antara inovasi dengan pertumbuhan perusahaan}

Inovasi merupakan pilar dasar pembangunan dan daya saing perusahaan saat ini. Beberapa penelitian telah dikhususkan untuk beberapa aspek dari inovasi terutama untuk hubungan antara inovasi dan kinerja (Damijan et al., 2012). Dengan melakukan inovasi, perusahaan memiliki kemungkinan lebih besar untuk menciptakan nilai, menciptakan kekayaan intelektual (Rafindaand Noveria, 2014). Dalam pada itu, Sorescu dan Spanjol (2008) menyimpulkan bahwa inovasi merupakan terobosan perusahaan untuk peningkatan keuntungan normal dan rente ekonomi, serta nilai perusahaan. Oleh karena itu dapat dirumuskan hipotesis sebagai berikut; 


\section{Inovasi, Pertumbuhan, Ukuran dan Nilai Perusahaan Farmasi di Indonesia}

Mursalim Nohong

$\mathrm{H}_{3}$ : Terdapat pengaruh signifikan antara inovasidengan nilai perusahaan

Inovasi menjadi andalan untuk mempertahankan pertumbuhan, pangsa pasar, dan keuntungan perusahaan dari gempuran pesaing yang makin gencar.Inovasi produk dan layanan, seringkali kurang memadai, inovasi harus hadir dalam segala sendi organisasi. Peran inovasi, semestinya tidak lagi hanya terbatas sebagai alat bagi pemecahan masalah yang dihadapi perusahaan. Inovasi juga berperan sebagai alat untuk menciptakan, meningkatkan, dan mempertahankan nilai perusahaan (Mursalim et al., 2015). Oleh karena itu dapat dirumuskan hipotesis sebagai berikut;

$\mathrm{H}_{4}$ : Terdapat pengaruh signifikan antara pertumbuhan perusahaan dengan ukuran perusahaan

Perusahaan yang tumbuh dengan cepat memperoleh hasil positif dalam artian pemantapan posisi di peta persaingan, menikmati penjualan yang meningkat secara signifikan dan diiringi oleh adanya peningkatan pangsa pasar. Pertumbuhan cepat juga memaksa sumber daya manusia yang dimiliki untuk secara optimal memberikan kontribusinya (Safrida, 2008).

Pertumbuhan perusahaan menjadi salah satu pertimbangan pihak internal dan eksternal perusahaan oleh karena pertumbuhan perusahaan merupakan representasi perkembangan perusahaan. Bagi investor, perusahaan yang bertumbuh menggambarkan bahwa perusahaan tersebut menguntungkan sehingga mendorong investor untuk meningkatkan penyertaan modalnya. Respon yang diberikan oleh investor tersebut merepresentasikan nilai perusahaan. Oleh karena itu dapat dirumuskan hipotesis sebagai berikut;

$\mathrm{H}_{5}$ : Terdapat pengaruh signifikan antara pertumbuhan perusahaan dengan nilai perusahaan
Ukuran perusahaan (size) merupakan cerminan besar kecilnya perusahaan yang nampak dalam nilai total aktiva perusahaan. Ukuran perusahaan pada dasarnya menggambarkan bahwa perusahaan tersebut mengalami pertumbuhan sehingga akan menarik perhatian investor maupun calon investor di pasar modal.

Semakin besar ukuran perusahaan, maka ada kecenderungan lebih banyak investor yang menaruh perhatian pada perusahaan tersebut. Semakin besar ukuran perusahaan, semakin besar pula kecederungan investor untuk memiliki saham sehingga berdampak kenaikan harga saham. Sementara itu, kenaikan harga saham akan mendorong peningkatan nilai perusahaan. Perusahaan yang besar dapat menyebabkan pasar akan mau membayar lebih mahal untuk mendapatkan sahamnya karena percaya akan mendapatkan pengembalian yang menguntungkan. Oleh karena itu, dapat dirumuskan hipotesis sebagai berikut:

$\mathrm{H}_{6}$ : Terdapat pengaruh signifikan antara ukuran perusahaan dengan nilai perusahaan

\section{METODE}

Berdasar pada masalah dan tujuan penelitian, maka penelitian ini termasuk jenis penelitian eksplanatif yang bertujuan memberikan penjelasan mengenai hubungan (kausalitas) antar variabel ukuran perusahaan, inovasi, pertumbuhan perusahaan dan nilai perusahaan melalui pengujian hipotesis.

Sampel penelitian adalah seluruh perusahaan farmasi yang terdaftar di Bursa Efek Indonesia (Sensus) periode 2011 - 2014. Sampel terpilih adalah 10 (sepuluh) perusahaan farmasi yang pada periode tersebut mempublikasikan data-data laporan keuangan yang menjadi variabel penelitian. Pengumpulan data dilakukan dengan metode dokumentasi melalui Indonesia Capital Market Directory (ICMD). 
Dalam melakukan analisis data, penelitian ini menekankan pada analisis kuantitatif. Analisis data dengan pendekatan kuantitatif dibagi menjadi analisis statistik deskriptif dan statistik inferensial. Analisis statistik deskriptif digunakan untuk mendeskripsikan variabel penelitian.Analisis statistik inferensial digunakan untuk menjelaskan hubungan kausal antar variabel.Metodestatistik inferensial yang digunakan dalam analisis data penelitian ini adalah Structural Equation Modeling (SEM) berbasis variance yang dikenal sebagai metode Partial Least Square (PLS).

Variabel-variabel yang digunakan dalam penelitian ini adalah pada tabel 1:
HASIL

\section{Uji Linieritas}

Uji ini dilakukan untuk mengetahui hubungan linieritas antar variabel.Berdasarkan perhitungan yang dilakukan diperoleh nilai signifikansi dan nilai F seperti pada tabel 2.

Goodness of Fit Model

1. Pengukuran variabel endogen pertumbuhan perusahaandiperoleh $\mathrm{R}^{2}$ sebesar 0,611 atau $61,1 \%$. Hal ini mengindikasikan sebesar $61,1 \%$ pertumbuhan perusahaandipengaruhi oleh inovasi.

2. Pengukuran variabel endogen ukuran perusahaandiperoleh $\mathrm{R}^{2}$ sebesar 0,841 atau $84,1 \%$. Hal

Tabel 1. Definisi Operasional Variabel Penelitian

\begin{tabular}{clcc}
\hline \multicolumn{1}{c}{ Variabel dan Konsep } & Indikator & Skala \\
\hline $\mathrm{X}_{1}$ & $\begin{array}{l}\text { Ukuran perusahaan } \\
\text { Merupakan nilai buku total asset perusahaan }\end{array}$ & $\begin{array}{l}\text { Nilai buku } \\
\text { total asset }\end{array}$ & Rasio \\
\hline $\mathrm{X}_{2}$ & $\begin{array}{l}\text { Inovasi } \\
\text { Merupakan biaya yang dikeluarkan perusahaan untuk kegiatan riset } \\
\text { dan pengembangan (R \& D) }\end{array}$ & Biaya R \& D & Rasio \\
\hline $\mathrm{X}_{3}$ & $\begin{array}{l}\text { Pertumbuhan perusahaan } \\
\text { Merupakan selisih antara penjualan tahun ini dengan penjualan } \\
\text { tahun sebelumna }\end{array}$ & $\begin{array}{l}\text { Penjualan } \mathrm{t}_{1}- \\
\text { Penjualan } \mathrm{t}-1\end{array}$ & Rasio \\
\hline $\mathrm{X}_{4}$ & $\begin{array}{l}\text { Nilai Perusahaan } \\
\text { Merupakan pencerminan keberhasilan perusahaan atas operasi } \\
\text { dimasa lalu dan prospek di masa yang akan datang }\end{array}$ & Tobins'Q & Rasio \\
\hline
\end{tabular}

Tabel 2. Hasil olah data uji linieritas

\begin{tabular}{cccc}
\hline $\begin{array}{c}\text { Hubungan } \\
\text { antar variabel }\end{array}$ & F & Signifikansi & Keterangan \\
\hline$X_{3} \rightarrow X_{1}$ & 0,321 & 0,896 & Linier \\
\hline$X_{2} \rightarrow X_{1}$ & 0,482 & 0,860 & Linier \\
\hline$X_{2} \rightarrow X_{3}$ & 0,137 & 0,998 & Linier \\
\hline$X_{2} \rightarrow X_{4}$ & 0,449 & 0,878 & Linier \\
\hline$X_{1} \rightarrow X_{4}$ & 0,148 & 0,968 & Linier \\
\hline$X_{3} \rightarrow X_{4}$ & 0,417 & 0,816 & Linier \\
\hline
\end{tabular}

Sumber: Data primer diolah, 2015 
ini mengindikasikan sebesar $84,1 \%$ ukuran perusahaan dipengaruhi oleh inovasi dan pertumbuhan perusahaan.

3. Pengukuran variabel endogen nilai perusahaandiperoleh $\mathrm{R}^{2}$ sebesar 0,897 atau $89,7 \%$. Hal ini mengindikasikan sebesar $89,7 \%$ nilai perusahaan dipengaruhi oleh ukuran perusahaan, inovasi, dan pertumbuhan perusahaan.

Dengan demikian nilai predictive relevance $\left(\mathrm{Q}^{2}\right)$ diperoleh sebagai berikut:

$\mathrm{Q}^{2}=1-\left(1-\mathrm{R}_{1}^{2}\right)\left(1-\mathrm{R}_{2}^{2}\right)\left(1-\mathrm{R}_{3}^{2}\right)$

$\mathrm{Q}^{2}=1-(1-0,611)(1-0,841)(1-0,897)$

$\mathrm{Q}^{2}=0,9936$

Hasil perhitungan memperlihatkan nilai predictive-relevance sebesar 0,9936atau 99,36\% bernilai sangat tinggi, sehingga model layak dikatakan memiliki nilai prediktif yang relevan. Nilai predictive relevance sebesar 99,36\% mengindikasikan bahwa keragaman data yang dapat dijelaskan oleh model PLS yang dibangun adalah sebesar 99,36\% atau dengan kata lain informasi yang terkandung dalam data 99,36\% dapat dijelaskan oleh model tersebut. Sedangkan sisanya $0,64 \%$ dijelaskan oleh variabel lain (yang belum terkandung dalam model) dan error.

\section{PEMBAHASAN}

Hasil olah data dengan menggunakan Partial Least Square (PLS) mengenai hubungan antar variabel seperti pada Tabel 3.

\section{Pengaruh inovasi terhadap ukuran perusahaan}

Hasil olah data seperti Nampak pada Tabel 3 diperoleh nilai 0,900 dan nilai $\tilde{n}$-value sebesar 0,000.Hal ini menunjukkan bahwa hipotesis yang

Tabel 3. Hasil pengujian hubungan antar variabel

\begin{tabular}{|c|c|c|c|c|}
\hline $\begin{array}{c}\text { Hubungan } \\
\text { antar variabel }\end{array}$ & Inner weight & $\begin{array}{c}\mathrm{T}- \\
\text { Statistik } \\
\end{array}$ & P - Value & Kesimpulan \\
\hline \begin{tabular}{l}
\multicolumn{2}{c}{$\mathrm{X}_{2} \rightarrow \mathrm{X}_{1}$} \\
$\begin{array}{l}\text { Pengaruhinovasi } \\
\text { perusahaan }\end{array}$ \\
\end{tabular} & 0.900 & 31.513 & 0.000 & Signifikan \\
\hline $\begin{array}{lcl} & X_{2} \rightarrow X_{3} & \\
\text { Pengaruh } & \text { inovasi } \\
\text { pertumbuhan perusahaan } & \text { terhadap } \\
\end{array}$ & 0.782 & 20.009 & 0.000 & Signifikan \\
\hline \begin{tabular}{lll}
\multicolumn{3}{c}{$\mathrm{X}_{2} \rightarrow \mathrm{X}_{4}$} \\
$\begin{array}{l}\text { Pengaruhinovasi } \\
\text { perusahaan }\end{array}$ & terhadap nilai \\
\end{tabular} & 0.759 & 10.986 & 0.000 & Signifikan \\
\hline $\begin{array}{l}\qquad \mathrm{X}_{1} \rightarrow \mathrm{X}_{3} \\
\text { Pengaruh pertumbuhan perusahaan } \\
\text { terhadap ukuran perusahaan }\end{array}$ & 0.278 & 2.465 & 0.050 & Signifikan \\
\hline $\begin{array}{l}\mathrm{X}_{3} \rightarrow \mathrm{X}_{4} \\
\text { Pengaruh pertumbuhan } \\
\text { terhadap nilai perusahaan }\end{array}$ & 0.265 & 1.666 & 0.157 & $\begin{array}{c}\text { Tidak } \\
\text { Signifikan }\end{array}$ \\
\hline $\begin{array}{l}\qquad X_{1} \rightarrow X_{4} \\
\text { Pengaruhukuran perusahaan terhadap } \\
\text { nilai perusahaan }\end{array}$ & 1.359 & 12.265079 & 0.000 & Signifikan \\
\hline
\end{tabular}

Sumber: Data primer diolah, 2015 
menyatakan terdapat hubungan signifikan antara inovasi terhadap ukuran perusahaan diterima. Inovasi yang dilakukan perusahaan farmasi dalam kaitannya dengan pengembangan produk dan teknologi seiring dengan perkembangan yang terjadi di dunia kesehatan.

Industri farmasidikenal sebagai industri padat pengetahuan(knowledge-based industry) dengan karakteristikbelanja $R \& D$ yang besar bahkan diharapkan melebihi rata-rataindustri. Pertimbangannya bahwa industri farmasi mempunyai peran penting dalam menjamin dan memperbaiki kesehatan masyarakat, menghasilkanobat untuk mengatasi berbagai penyakit,minimasi risiko kesehatan dan menjaminpelayanan kesehatan yang berkesinambungan(sustainable) bagi generasi sekarang maupungenerasi mendatang.

Hasil penelitian ini memperkuat berlakunya transaction costs theoryyang diperkenalkan oleh Coase (1937). Coase (1997) mengemukakan bahwa ukuran perusahaan tergantung pada karakteristik perilaku (Williamson, 1975) dan karakteristik transaksi. Karakteristik tersebut akan berubah secara terus menerus seiring dengan pembangunan ekonomi dan institusi yang mengarah pada level tertinggi inovasi. Dengan kata lain bahwa inovasi akan mendorong perkembangan institusi yang secara langsung meningkatnya ukuran perusahaan.

\section{Pengaruh inovasi terhadap pertumbuhan perusahaan}

Seperti nampak pada Tabel 3 bahwa nilai pengaruh inovasi terhadap pertumbuhan perusahaan adalah sebesar 0,782 dan nilai $\rho$-value sebesar 0,000. Hal tersebut menunjukkan bahwa hipotesis yang menyatakan terdapat pengaruh signifikan antara inovasi dengan pertumbuhan perusahaan diterima.Hasil penelitian ini mendukung penelitian yang dilakukan oleh Cameron (1998) dan Love dan Roper (2013).
Respon perusahaan farmasi terhadap permintaan pasar berkembang seiring dengan peningkatan kebutuhan masyarakat terhadap kesehatan. Dengan inovasi produk yang dilakukan, maka ketersediaan produk-produk farmasi dan sejenisnya akan mendorong pertumbuhan perusahaan perusahaan.

\section{Pengaruh inovasi terhadap nilai perusahaan}

Ketertarikan investor terhadap perusahaan salah satunya disebabkan oleh kebijakan perusahaan dalam mengelola dana yang ditanamkan oleh investor. Pengelolaan dana dapat ditunjukkan pada aktifitas inovasi perusahaan. Oleh karena itu, semakin inovatif sebuah perusahaan maka respon investor akan semakin tinggi. Respon tinggi akan berdampak pada peningkatan nilai perusahaan.

Hasil olah data penelitian diperoleh nilai sebesar 0.759 dan nilai $\rho$-value sebesar 0,000 , maka dapat disimpulkan bahwa hipotesis yang menyatakan terdapat pengaruh signifikan antara inovasi dengan nilai perusahaan diterima.Hasil penelitian ini sejalan dengan penelitian Rafinda dan Noveria (2013).Oleh karena itu dapat dikemukakan bahwa semakin tinggi alokasi biaya atau anggaran perusahaan untuk kegiatan inovasi maka nilai perusahaan akan semakin tinggi.

\section{Pengaruh pertumbuhan perusahaan terhadap ukuran perusahaan}

Pertumbuhan perusahaan merupakan proses yang terjadi secara gradual dalam perusahaan. Pertumbuhan perusahaan yang dalam penelitian ini diindikasikan dengan pertumbuhan penjualan akan mendorong berkembangnya perusahaan. Pertumbuhan penjualan selain menjadi indikator kinerja juga memiliki dampak terhadap aktifitas investasi yang dilakukan perusahaan. Investasi tersebut akan mendorong berkembangnya asset perusahaan. 


\section{Inovasi, Pertumbuhan, Ukuran dan Nilai Perusahaan Farmasi di Indonesia \\ Mursalim Nohong}

Hasil olah data diperoleh nilai 0,278 dan $\rho-$ value sebesar 0,050 yang berarti bahwa hipotesis yang menyatakan terdapat pengaruh signifikan antara pertumbuhan perusahaan terhadap ukuran perusahaan diterima.

\section{Pengaruh pertumbuhan perusahaan terhadap nilai perusahaan}

Investor memiliki perhatian terhadap perkembangan atau pertumbuhan perusahaan. Hal tersebut didasari oleh dana yang ditanamkan pada perusahaan. Pertumbuhanyang baik memberi tanda bagiperkembangan perusahaan. Dari sudut pandang investor, pertumbuhan suatuperusahaan merupakan tanda perusahaan memiliki aspek yang menguntungkan, dan investor pun akan mengharapkan tingkat pengembalian (rate of return) dari investasi yang dilakukan menunjukkan perkembangan yang baik.

Hasil perhitungan diperoleh 0.265 dan $\rho$ value sebesar 0,157 yang berarti bahwa hipotesis yang menyatakan terdapat pengaruh signifikan pertumbuhan perusahaan terhadap nilai perusahaan ditolak.Hasil penelitian ini berbeda dengan penelitian yang dilakukan oleh Shin dan Stulz (2000) yang menjelaskan bahwa perusahaan nilai perusahaan meningkat seiring dengan pertumbuhan perusahaan.

\section{Pengaruh ukuran perusahaan terhadap nilai perusahaan}

Ukuran perusahaan merupakan cerrminan besar kecilnya perusahaan diindikasikan dengan nilai total aktiva perusahaan. Berdasarkan hal tersebut, maka semakin besar ukuran perusahaan, ada kecenderungan investormenaruh perhatian pada perusahaan.Respon yang diberikan oleh investor tersebut disebabkan karenaperusahaan besar memiliki kondisi yang lebih stabil sehingga menarik minat investor untuk memiliki saham per- usahaan. Peningkatanpermintaan saham perusahaan akan memacu peningkatan harga sahamdi pasar modal sehingga "nilai" perusahaan juga akan meningkat.

Hasil olah data diperoleh 1,359 dengan $\rho$ value sebesar 0,000.Perolehan nilai tersebut juga menunjukkan bahwa hipotesis yang menyatakan terdapat pengaruh signifikan antara ukuran perusahaan dengan nilai perusahaan diterima.Hasil penelitian ini memperkuat temuan penelitian Soliha dan Taswan (2002). Berdasarkan hasil kedua penelitian tersebut, maka dapat dikatakan bahwa semakin besar perusahaan nilai perusahaan akan semakin besar.

\section{KESIMPULAN}

Aktivitas inovasi perusahaan merupakan salah satu kebijakan strategis yang memiliki keterkaitan dengan kebijakan perusahaan lainnya seperti investasi dan pendanaan.Oleh karena itu, keputusan perusahaan untuk melakukan tindakan inovasi harus sejalan dengan kebutuhan konsumen serta mempertimbangkan kemampuan perusahaan. Kekeliruan yang terjadi dalam inovasi justru akan menjadi masalah bagi perusahaan mengingat inovasi memerlukan dana dalam jumlah besar.

Hasil penelitian ini menunjukkan bahwa inovasi perusahaan farmasi pada periode 2010 - 2014 mampu meningkatkan ukuran perusahaan, pertumbuhan perusahaan, dan nilai perusahaan. Inovasi yang dilakukan oleh perusahaan farmasi berfokus pada inovasi produk, pelayanan dan bisnis model. Inovasi produk didasarkan pada pembaruan penawaran produk yang selama ini ada dipasar. Inovasi pelayanan jika produk yang sebelumnya didistribusikan untuk jasa/pelayanan, maka hal tersebut merupakan cara mengakses pelanggan (customer) yang diadopsi oleh organisasi. Inovasi bisnis model dilakukan dengan cara; 1). Menetapkan kembali bagaimana organisasi menawarkan produk dan / atau jasa kepada konsumen, 2). Memberikan nilai tambah selama proses transaksi dengan pelanggan dilakukan. 


\section{Jurnal Keuangan dan Perbankan | KEUANGAN}

Vol. 20, No.2, Mei 2016: 176- 185

\section{SARAN}

Pengaruh pertumbuhan perusahaan terhadap nilai perusahaan dalam penelitian ini positif tapi tidak signifikan.Kenyataan ini menggambarkan bahwa ekspektasi investor terhadap pertumbuhan perusahaan yang direpresentasikan oleh pertumbuhan penjualan belum sepenuhnya optimal dalam meningkatkan nilai perusahaan. Investor menginginkan pertumbuhan penjualan lebih besar dari capaian selama ini sehingga dana yang diinvestasikan mampu meningkatkan kesejahteraan dan nilai perusahaan.

Periode penelitian ini hanya lima tahun sehingga peneliti di masa yang akan datang memperluas cakupan waktu penelitian. Peneliti lainnya juga dapat memilih obyek penelitian khususnya perusahaan-perusahaan yang rutin dalam melakukan inovasi dengan mengacu tidak hanya pada biaya riset dan pengembangannya.

\section{DAFTAR PUSTAKA}

Belenzon, Sharon., Patacconi, Andrea. 2013. Innovation and firm value: An investigation of the changing role of patents, 1985-2007. Research Policy.42, 8.

Berzkalne, Irina and Zelgalve, Elvira. 2014. Innovation And Company Value: Evidence From The Baltic Countries. Regional Formation and Development Studies, 3,11 .

Bishop, K., Mason, G., Robinson, C., 2009. Firm growth and its effects on economic and social outcomes. National Institute of Economic and Social Research,London.

Bosma, Niels and de Wit, Gerrit. 2004. The influence of innovation on firmsizeSCALES-paper N200318.

Cainelli, G., R. Evangelista and M. Savona. 2006. Innovation and Economic Performance inServices: A Firm Level Analysis. Cambridge Journal of Economics. 30, 435-458.

Cameron,Gavin. 1998. Innovation and Growth: A Survey of the Empirical Evidence. Thesis.TheUniversity of Oxford.
Cefis E and Ciccarelli M. 2005.Profit differentials and innovation.Economics of Innovation and New Technology, 14, 43-61.

Coase, R.H. 1937. The nature of the firm.Economica, 4, 386-405.

Damijan, J.P., Kostevc, C., Rojec, M., 2012. Does innovation help the good or the poor performing firms?.Economics Letters. 115, 2, 190-195.

Drucker, P.F. 1985. The Practice of Innovation, Innovation and Entrepreneurship Practiceand Principles, Harper \& Row, New York, pp. 19-33.

Erlangga, Enggar dan Suryandari, Erni. 2009. Pengaruh Kinerja Keuangan terhadap Nilai Perusahaan dengan Pengungkapan CSR, Good Corporate Governance dan Kebijakan Dividen Sebagai Variabel Pemoderasi. Jurnal Akuntansi dan Investasi, 10,1 .

Geroski P, Van Reenen J and Walters C F. 1997. How persistently do firms innovate? Research Policy, 26, 33-48.

Leiponen A. 2000. Competencies, innovation and profitability of firms.Economics of Innovation and New Technology, 9, 1-24.

Love, James H and Roper, Stephen. 2013. SME innovation, exporting and Growth: A review of existing evidence. www.enterpriseresearc.ac.uk

Mason, Geoff, Bishop, Kate and Robinson, Catherine. 2009. Business Growth and Innovation; The wider impact of rapidly-growingfirms in UK city-regions. Research report NESTA, October.

Moore, G. 2004. Darwin and the demon: Innovating within established enterprises.Harvard Business Review, 82(7/8), 86-91.

Mursalim, Hendragunawan, Nur Alamzah, dan Abdullah Sanusi. 2015. Financial Decision, Innovation, Profitability and Company Value: Study on Manufacturing Company Listed in Indonesian Stock Exchange. Information Management and Business Review, Vol. 7, No. 2, pp. 72-78

Nicolau, Juan Luis and María Jesús Santa-María. 2013. Communicating Excellence In Innovation. Economics Letters. Volume 118, Issue 1, 87-90. 


\section{Inovasi, Pertumbuhan, Ukuran dan Nilai Perusahaan Farmasi di Indonesia}

Mursalim Nohong

Rafinda, Ascariena and Noveria, Ana. 2014. Examining the Relationship between Innovation And Company Values of Apple Inc. International Conference on Trends in Economics, Humanities and Management (ICTEHM'14).

Safrida, Eli. 2008. Pengaruh Struktur Modal dan Pertumbuhan Perusahaan Terhadap Nilai Perusahaan pada Perusahaan Manufaktur di Bursa Efek Jakarta. Tesis tidak dipublikasikan

Schumpeter, J. 1949. Economic Theory and Entrepreneurial History, Change and the Entrepreneur, pp. 63-84, reprinted in Schumpeter, J. 1989. Essays on Entrepreneurs, Innovations, Business Cycles and the Evolution of Capitalism, edited by Richard V. Clemence, New Brunswick, N.J.: Transaction Publishers, pp. 253- 231.

Shin, Hyun-Han and Stulz, Rene. 2000. Firm Value, Risk, and Growth Opportunities. Working Paper 7808.
Soliha, E dan Taswan.2002. PengaruhKebijakan Hutang Terhadap NilaiPerusahaan Serta Beberpa Faktor yangMempengaruhinya.Jurnal Bisnis danEkonomi. (online), (www.google.com).

Sundbo, J. 1997. Management of innovation in services.The Service Industries Journal, 17(3), 432455.

Swan, J., Newel, H., Scarbrought, and Hislop. 1999. Knowledge Management and Innovations: Networks and Networking. Journal of Knowledge Management, 3(4): 262"275.

Treacy, Michael. 2013. Management: A Global Innovative, Innovation and Entrepreneurial Perspective, 14/e, McGraw Hill Education (India).

Williamson, O.E. 1975. Markets and Hierarchies: Analysis and Antitrust Implications. New York, Free Press.

Zemplinerová, Alena and Hromádková, Eva. 2012. Determinants of Firm's Innovation, Prague Economic Papers, 4. 